Sandler; Medisch Centrum Alkmaar: C Burgersdijk, J Ruiter; St Franciscus Ziekenhuis, Roosendaal: RJ Bos; Akademika Sjukhuset, Uppsala: B Lagerqvist; Hospital de la Princesa, Madrid: C Romero, X Ruiz-Ocana, A Reyes; Hospital de la Santa Creu i Sant Pau, Barcelona: J Garcia-Moll, X GarciaPicart.

Members of the steering committee were M Verstraete (chairman), F Van de Werf (Leuven), DP de Bono (Edinburgh), $\mathrm{R}$ von Essen (Munich), RJ Lennane, I Welbers (Ingelheim), J Lubsen, PW Serruys, ML Simoons (Rotterdam), W Rutsch (Berlin), and A Vahanian (Paris).

Members of the data monitoring and ethical committee were $\mathrm{J}$ Hampton (Nottingham), DG Julian (Newcastle upon Tyne), W Schaper (Bad Nauheim), L Wilhelmsen (Gothenburg), and D Wood (Southampton).

Members of the angiography assessment group were DP de Bono (chairman, Edinburgh), WS Hillis (Glasgow), DS Reid (Newcastle upon Tyne), W Rutsch (Berlin), PW Serruys
(Rotterdam), R Uebis (Aachen), and A Vahanian (Paris). Members of the ECG assessment group were JL Willems (Leuven), W Schmidt, and R Dörr (Aachen).

Members of the exercise test assessment group were $\mathrm{R}$ von Essen (Munich) and JM Detry (Brussels).

Members of the radionuclide assessment group were J Vanhaecke, L Mortelmans (Leuven), and J Melin (Brussels).

Members of the data coordinating centre were AER Arnold, $M$ Bokslag, EPM Bos-Wolvers, RW Brower, I van Oosterom-de Waard, KM Hoolboom-Neissen, HF Eldering-Gerritsen, and J Lubsen (Rotterdam).

Members of the core laboratory for enzyme determination were WT Hermens, GM Willems (Maastricht).

Members of the core laboratory for quantitative angiography were PW Serruys, AER Arnold, KM Hoolboom, and C Tirtaman (Rotterdam).

Members of the central coagulation laboratory were D Collen and HR Lijnen (Leuven).

\title{
Consequences of fetomaternal haemorrhage after intrauterine transfusion
}

\author{
Umberto Nicolini, Neil K Kochenour, Pantaleo Greco, Elizabeth A Letsky, Robert D Johnson, \\ Marcela Contreras, Charles H Rodeck
}

\begin{abstract}
Fetomaternal haemorrhage was studied after 68 consecutive fetal intravascular transfusions performed in 20 patients with $R h$ isoimmunisation. $\alpha$ Fetoprotein concentration was assayed in maternal blood taken before, and immediately after each transfusion and three and 24 hours later. An increase of $50 \%$ or more in the concentration in any of the samples after transfusion was considered to indicate fetomaternal haemorrhage. Fetal $\alpha$ fetoprotein concentration in blood sampled before transfusion was also assayed and the amount of fetomaternal haemorrhage calculated. Fetomaternal haemorrhage occurred in 21 of 32 patients with an anterior placenta and in six of 36 with a posterior or fundal placenta. The mean estimated volume of haemorrhage was $2.4 \mathrm{ml}$, which was on average equal to $3 \cdot 1 \%$ of the total fetoplacental blood volume. When the volume of fetomaternal haemorrhage at the first transfusion was greater than $1 \mathrm{ml}$ there was a greater increase in maternal $\mathbf{R h}(D)$ antibody titres and a greater fall in fetal packed cell volume.

Sampling of fetal blood should not be routinely done early in patients with $\mathrm{Rh}$ isoimmunisation, and intrauterine transfusion should be delayed as long as possible. Sampling sites other than the placental cord insertion reduces the risk of fetomaternal haemorrhage.
\end{abstract}

\section{Department of Haematology, Queen Charlotte's Hospital Elizabeth A Letsky, FRCPATH, consultant}

Department of Chemical Pathology, Queen Charlotte's Hospital Robert D Johnson, PHD, senior biochemist

North London Blood Transfusion Centre, Edgware, Middlesex HA8 9BD

Marcela Contreras,

FRCPATH, director

Correspondence to:

Professor Rodeck.
Rodeck et al achieved good results with fetoscopy but Mackenzie et al did not, ${ }^{6}$ and transabdominal needling is now used by most centres as it is easier and safer. A fetal mortality of about $1 \%$ was reported by Daffos et al in a large series of diagnostic samplings,? though the rate is probably higher in fetuses with $\mathrm{Rh}$ haemolytic disease as the procedure is usually done several times. Reports of several series have claimed that this technique is the first choice in the management of patients with $\mathrm{Rh}$ isoimmunisation. Direct access to the fetal circulation avoids the problems of indirect tests such as spectrophotometry of the amniotic fluid in evaluating the severity of the disease. ${ }^{8}$

Transplacental ultrasound guided needling may result in fetomaternal haemorrhage, which in cases of $\mathrm{Rh}$ isoimmunisation may increase the severity of the disease by enhancing the maternal immunological response to fetal antigens. Fetomaternal haemorrhage has been investigated after amniocentesis ${ }^{90}$ and fetoscopy ${ }^{11}$ but not after transabdominal needling. We therefore studied the occurrence of fetomaternal haemorrhage in patients undergoing intrauterine transfusions for $\mathrm{Rh}$ haemolytic disease by transabdominal needling. The severity of the haemorrhage was related to the site of sampling and to changes in maternal antibody titres and fetal packed cell volumes after transfusion.

\section{Patients and methods}

Fetomaternal haemorrhage was studied after 68 consecutive fetal intravascular transfusions performed from November 1986 to June 1987 in 20 patients with $\mathrm{Rh}$ isoimmunisation. Fourteen procedures were the first performed in each patient and 54 were subsequent ones. Gestational ages ranged between 18 and 33 weeks. All the transfusions were performed by transabdominal needling under continuous ultrasonic control with a 20 gauge spinal needle. Fetal blood (2 $\mathrm{ml}$ ) was taken for immediate estimation of packed cell volume (Coulter Channelyzer) before transfusion of packed erythrocytes from $\mathrm{Rh}$ negative donors, which had been cross matched with maternal blood.

The site of sampling and transfusion was the placental cord insertion in 47 procedures and the intrahepatic vein, fetal umbilical cord insertion, or free cord in the remaining 21 . The umbilical artery was not sampled. The placenta was mainly anterior in 32 patients and posterior or fundal in 36 . 
The aim of intravascular transfusion was to raise the fetal packed cell volume to about $0 \cdot 4$. The rate of infusion of donor blood (packed cell volume $0 \cdot 6-0 \cdot 8$ ) was $1-7 \mathrm{ml} / \mathrm{min}$. Throughout the procedure the fetal heart rate and the flow of transfused blood in the umbilical vein were monitored continuously by ultrasonography. In 46 procedures an intraperitoneal transfusion was carried out immediately after the intravascular transfusion. In all cases the whole procedure was accomplished within 45 minutes.

Maternal blood $(2 \mathrm{ml})$ was taken before and immediately after the procedure and then three and 24 hours later. Serum from the fetal sample taken before the transfusion and the maternal samples was frozen. Maternal serum samples were assayed subsequently for $\alpha$ fetoprotein. An increase of $50 \%$ or more in the $\alpha$ fetoprotein concentration in any of the samples taken after the transfusion was considered to indicate fetomaternal haemorrhage. Fetal serum samples from those patients who showed haemorrhage were also assayed for $\alpha$ fetoprotein. The volume of haemorrhage was estimated by the formula $\mathrm{AB} / \mathrm{C}(1-\mathrm{P})$, where $\mathrm{A}=$ increase in maternal $\alpha$ fetoprotein concentration, $\mathrm{B}=$ maternal plasma volume,${ }^{12} \mathrm{C}=$ fetal $\alpha$ fetoprotein concentration, and $P=f e t a l$ packed cell volume. Haemorrhage was also expressed as a percentage of the estimated total fetoplacental blood volume for gestational age. ${ }^{13}$

$\mathrm{Rh}$ (D) antibodies were assayed before the first transfusion and then three weeks later. The rate of fall in fetal packed cell volume was also calculated in these patients as the fetal packed cell volume after the first transfusion minus the fetal packed cell volume before the second transfusion divided by the interval (in days).

The data were analysed with the $\chi^{2}$ test or Fisher's exact test when appropriate and Student's $t$ test when the population was normally distributed; when this was not the case data were transformed logarithmically and the Mann-Whitney test used for comparison of two populations.

\section{Results}

Fetomaternal haemorrhage occurred after 27 of the 68 intrauterine transfusions. The mean estimated volume of fetomaternal haemorrhage was $2.4 \mathrm{ml}$ (confidence interval 1.5 to $3 \cdot 7$; range $0 \cdot 3-15 \cdot 4$ ), which was on average equal to $3 \cdot 1 \%$ of the total volume of fetoplacental blood $(2 \cdot 2$ to $4 \cdot 5 ; 0 \cdot 5-14 \cdot 0)$. A significant positive correlation $(\mathrm{r}=0.60, \mathrm{p}<0.01)$ was found between the absolute volume of haemorrhage and gestational age, but no correlation was found between haemorrhage expressed as a percentage of the total volume of fetoplacental blood and gestational age.

An increase in maternal $\alpha$ fetoprotein concentration greater than $50 \%$ was found in 21 of the 32 patients with an anterior placenta and in six of the 36 with a posterior placenta; this difference was significant $(p<0.001)$. When the site of sampling and transfusion was the placental cord insertion fetomaternal haemorrhage occurred in 18 patients with an anterior placenta and in five with a posterior placenta, whereas when it

TABLE I-Incidence of fetomaternal haemorrhage in relation to site of sampling

\begin{tabular}{|c|c|c|c|c|}
\hline \multirow{7}{*}{$\begin{array}{l}\text { Anterior placenta } \\
\text { Placental cord insertion } \\
\text { Intrahepatic vein, free cord, umbilical } \\
\text { cord insertion } \\
\text { Posterior or fundal placenta } \\
\text { Placental cord insertion } \\
\text { Intrahepatic vein, free cord, umbilical } \\
\text { cord insertion }\end{array}$} & \multirow{2}{*}{\multicolumn{2}{|c|}{$\begin{array}{c}\begin{array}{c}\text { No with } \\
\text { haemorrhag }\end{array} \\
21\end{array}$}} & \multicolumn{2}{|c|}{$\begin{array}{l}\text { No without } \\
\text { haemorrhage }\end{array}$} \\
\hline & & & & 11 \\
\hline & 18 & & 4 & \\
\hline & 3 & & 7 & \\
\hline & & 6 & & 30 \\
\hline & 5 & & 20 & \\
\hline & 1 & & 10 & \\
\hline
\end{tabular}

TABLE II-Changes in maternal $R h(D)$ antibody concentrations after first intravascular transfusion in relation to volume of fetomaternal haemorrhage

\begin{tabular}{|c|c|c|c|c|}
\hline \multirow[b]{2}{*}{ Case No } & \multirow[b]{2}{*}{$\begin{array}{l}\text { Fetomaternal } \\
\text { haemorrhage } \\
(\mathrm{ml})\end{array}$} & \multicolumn{3}{|c|}{ Rh D antibody concentrations } \\
\hline & & $\begin{array}{l}\text { At intrauterine } \\
\text { transfusion } \\
(\mathrm{IU} / \mathrm{ml})^{\star}\end{array}$ & $\begin{array}{l}\text { After } 3 \text { weeks } \\
(\mathrm{IU} / \mathrm{ml})^{\star}\end{array}$ & $\begin{array}{c}\text { Change } \\
(\%)\end{array}$ \\
\hline 1 & & $40 \cdot 2$ & $42 \cdot 0$ & +4 \\
\hline 2 & & $10 \cdot 5$ & $15 \cdot 2$ & +45 \\
\hline 3 & & $117 \cdot 0$ & $266 \cdot 0$ & +127 \\
\hline 4 & & $27 \cdot 1$ & $23 \cdot 0$ & -15 \\
\hline 5 & 0.3 & $48 \cdot 0$ & $43 \cdot 0$ & -12 \\
\hline 6 & 0.7 & 116.0 & $111 \cdot 0$ & -5 \\
\hline 7 & 0.8 & $117 \cdot 0$ & 166.0 & +42 \\
\hline 8 & $1 \cdot 1$ & $412 \cdot 0$ & $384 \cdot 0$ & -7 \\
\hline 9 & $1 \cdot 1$ & $9 \cdot 3$ & $307 \cdot 5$ & +3206 \\
\hline 10 & 1.5 & $44 \cdot 0$ & $2075 \cdot 0$ & +4616 \\
\hline 11 & $1 \cdot 7$ & $12 \cdot 3$ & $102 \cdot 0$ & +729 \\
\hline 12 & $2 \cdot 7$ & $915 \cdot 0$ & $420 \cdot 0$ & -54 \\
\hline 13 & $4 \cdot 0$ & $37 \cdot 9$ & $442 \cdot 0$ & +1066 \\
\hline 14 & $7 \cdot 8$ & $13 \cdot 1$ & $62 \cdot 0$ & +373 \\
\hline
\end{tabular}

$\star 5 \mathrm{IU}=1 \mu \mathrm{g} \operatorname{Rh}(\mathrm{D})$ antibodies.

was the intrahepatic umbilical vein or free cord the figures were three and one respectively (table I). The difference was significant $(p<0.05)$ for those patients with an anterior placenta but not for those with a posterior placenta.

The need for a second transabdominal needle puncture for an intraperitoneal transfusion did not increase the risk of haemorrhage, which occurred in 15 of the 46 patients compared with 12 out of 22 who did not have an intraperitoneal transfusion.

Table II relates the changes in maternal $\mathrm{Rh}$ (D) antibody concentrations to the volume of fetomaternal haemorrhage at the first transfusion. In those cases in which haemorrhage did not occur or was less than $1 \mathrm{ml}$ the increase in $R h(D)$ concentration was always less than $150 \%$, whereas five of the seven patients in whom haemorrhage was more than $1 \mathrm{ml}$ had an increase of over $150 \%$. In the two groups the median increase in antibody titre was $4 \%$ (range $-15 \%$ to $127 \%$ ) and $729 \%$ $(-54 \%$ to $3206 \%)$ respectively; the difference was not significant. The rate of fall in fetal packed cell volume after the first transfusion was higher in those patients with a fetomaternal haemorrhage greater than $1 \mathrm{ml}$ (mean $1.36 \%$ /day; confidence interval 0.93 to 1.78 ; range $0 \cdot 7-2 \cdot 0$ ) than in those with haemorrhage of less than $1 \mathrm{ml}(0.97 \% /$ day; 0.63 to $1.32 ; 0.5-1.4)$; the difference, however, was not significant.

\section{Discussion}

Transabdominal needling of the umbilical cord, especially if the cord insertion is on an anterior placenta, differs from other procedures as it seems to break the rule that penetration of the placenta should be avoided. Several reports have associated transplacental amniocentesis and fetoscopy with fetomaternal haemorrhage, and in fetoscopy intraamniotic bleeding from the placenta makes visualisation difficult and may lead to severe fetal anaemia. ${ }^{14}$ In contrast a transplacental approach is deliberately chosen to needle the cord insertion of an anterior placenta.

Simpson et al emphasised the danger of fetal sensitisation to maternal red cell antigen after fetoscopy. They reported a mean increase in maternal serum $\alpha$ fetoprotein concentration of $212 \mu \mathrm{g} / \mathrm{l}$ after fetoscopic blood sampling. ${ }^{11}$ This is approximately equivalent to $0.5 \mathrm{ml}$ of fetomaternal haemorrhage. Haemorrhage can occur spontaneously, but Tabor et al did not find an increase in maternal serum $\alpha$ fetoprotein concentration of more tha $50 \%$ in any of 268 control patients between 14 and 23 weeks' gestation, while this occurred in $15.6 \%$ of patients who underwent amniocentesis at between 14 and 19 weeks. ${ }^{10}$ We used the same 
threshold and showed a $40 \%$ incidence of fetomaternal haemorrhage with a significant difference according to the site of the placenta.

Administration of anti-D immunoglobulin is routine after invasive procedures in $\mathrm{R} h$ negative patients but is not appropriate for those already sensitised, in whom it would be ineffective. ${ }^{15}$ In patients undergoing intrauterine transfusions, however, fetomaternal haemorrhage may enhance maternal sensitisation. Not only might the disease be worsened in a subsequent preg nancy but also in the present pregnancy the rate of fall in fetal packed cell volume might be accelerated by an increase in maternal antibody titre, particularly after the first transfusion, when fetal erythropoiesis is generally not yet suppressed.

Precisely estimating the volume of fetomaternal haemorrhage is difficult. In patients undergoing intrauterine transfusions the Kleihauer-Betke test cannot be used because donor red cells cannot be identified in the maternal circulation. The increase in maternal $\alpha$ fetoprotein concentration can give a reliable estimate if fetal $\alpha$ fetoprotein concentration is also assayed. Possible sources of error are the estimated maternal blood volume, which cannot practically be assessed in each patient, and passage of $\alpha$ fetoprotein into the maternal circulation from fluids other than fetal blood, such as the amniotic fluid. This second possibility is unlikely as fetomaternal haemorrhage occurred most commonly when the site of sampling and transfusion was the placental cord insertion with an anterior placenta-that is, when the needle entered directly into the cord without any communication with the amniotic cavity. Moreover, any contribution of $\alpha$ fetoprotein from the amniotic fluid to the rise in maternal $\alpha$ fetoprotein concentration should be irrelevant as the concentration in fetal blood is more than 100 times that in amniotic fluid. ${ }^{16}$

De Silva et al reported that $0.28 \mathrm{ml}$ of red cells produced a secondary $\mathrm{Rh}$ immune response in all of their 14 volunteers ${ }^{17}$; in our study the increase in maternal $\mathrm{Rh}(\mathrm{D})$ antibody concentration was clinically important when the volume of haemorrhage was greater than $1 \mathrm{ml}$. As the mean fetal packed cell volume at the first transfusion was $0 \cdot 20$ (range $0 \cdot 08-0 \cdot 31$ ) the results were comparable. In some instances the rise in antibody titre was dramatic, and although the consequences were not important as far as the rate of fall in fetal packed cell volume was concerned, the course of the disease in a subsequent pregnancy will probably be affected.

These results also suggest that sampling of fetal blood in patients with $\mathrm{Rh}$ isoimmunisation should not be routinely done for blood grouping early in pregnancy. It would be without consequence in $R h$ negative fetuses but might convert a mild case into a severe one if a considerable increase in maternal antibody titres was provoked by the procedure. Because fetomaternal haemorrhage can also occur in patients with posterior placentas, albeit less commonly, the risk of further sensitisation is present in all patients. The optimal time for intrauterine transfusion is the latest possible gestational age before fetal anaemia becomes severe. Other sites of sampling and transfusion can be chosen instead of the placental cord insertion, especially at the first transfusion, when fetomaternal haemorrhage would transfer only fetal cells. This policy would considerably reduce the risk of haemorrhage.

1 Rodeck CH, Nicolaides KH, Warsof SL, Fish WJ, Gamsu HR, Kemp JR. The management of severe rhesus isoimmunization by fetoscopic intravascular transfusions. Am f Obstet Gynecol 1984;150:769-74.

2 Bang J, Bock JE, Trolle D Ultrasound-guided fetal intravascular transfusion for severe rhesus haemolytic disease. Br Med f 1982;284:373-4.

3 de Crespigny LC, Robinson HP, Quinn M, Doyle L, Ross A, Cauchi M. Ultrasound-guided fetal blood transfusion for severe rhesus isoimmunization. Obstet Gynecol 1985;66:529-32.

4 Berkowitz RL, Chitkara U, Goldberg JD, Wilkins I, Chervenak FA, Lynch L. Intrauterine intravascular transfusions for severe red blood cell isoimmunization: ultrasound-guided percutaneous approach. Am $\mathcal{J}$ Obstet Gynecol 1986;155:574-81

5 Socol ML, MacGregor SN, Pielet BW, Tamura RK, Sabbagha RE Percutaneous umbilical transfusion in severe rhesus isoimmunization: resolution of fetal hydrops. Am $\mathcal{F}$ Obstet Gynecol 1987;157:1369-75.

6 MacKenzie IZ, Bowell PJ, Ferguson J, Castle BM, Entwistle CC. In-utero intravascular transfusion of the fetus for the management of severe rhesus isoimmunization - a reappraisal. Br f Obstet Gynaecol 1987;94:1068-73.

7 Daffos F, Capella-Pavlovsky M, Forestier F. Fetal blood sampling during pregnancy with use of a needle guided by ultrasound: a study of 606 consecutive cases. Am f Obstet Gynecol 1985;153:655-60.

8 Nicolaides $\mathrm{KH}$, Rodeck CH, Mibashan RS. Have Liley charts outlived their usefulness? Am $\mathcal{F}$ Obstet Gynecol 1986;155:90-4.

9 Lele AS, Carmody PJ, Hurd ME, O'Leary JA. Fetomaternal bleeding following diagnostic amniocentesis. Obstet Gynecol 1982;60:60-4

10 Tabor A, Bang J, Norgaard-Pedersen B. Feto-maternal haemorrhage associated with genetic amniocentesis: results of a randomized trial. Br $\mathcal{F}$ Obste Gynaecol 1987;94:528-34.

11 Simpson GF, Sun NH, Golbus MS. Changes in maternal serum alphafetoprotein levels associated with intrauterine genetic diagnostic procedures. Prenat Diagn 1984;4:207-11.

12 Hytten FE, Paintin DB. Increase in plasma volume during normal pregnancy. Journal of Obstetrics and Gyneocology of the British Commonwealth 1963;70: 402-7.

13 Nicolaides KH, Clewell WH, Rodeck CH. Measurement of blood volume in erythroblastosis fetalis. Am $\mathcal{J}$ Obstet Gynecol 1987;157:50-3.

14 Nicolini U, Hertogs $\mathrm{K}$, Rodeck $\mathrm{CH}$. Sinusoidal rhythm caused by fetal haemorrhage during fetoscopy. F Perinat Med 1984;12:39-42.

15 Bowman JM, Pollock JM. Reversal of Rh alloimmunization. Fact or fancy? Vox Sang 1985;48:209-15.

16 Forestier F, Daffos F, Rainout M, Bruneau M, Trivin F. Blood chemistry of normal human fetuses at midtrimaster of pregnancy. Pediatr Res 1987;21 579-83.

17 de Silva M, Contreras M, Mollison PL. Failure of passively administered anti-Rh to prevent secondary Rh responses. Vox Sang 1985;48:178-80.

(Accepted 5 September 1988)

\section{Department of Otolaryngology, University of Glasgow, Royal Infirmary, Glasgow G4 OSF G G Browning, MD, reader I R C Swan, MD, senior lecturer}

Correspondence to: Mr Browning.

\section{Sensitivity and specificity of Rinne tuning fork test}

\section{G G Browning, I R C Swan}

The Rinne tuning fork test is used regularly by specialists and non-specialists in patients with hearing impairments to indicate whether there is a conductive (external or middle ear) component to their deafness. Its ability to do this can be judged only by its sensitivity and specificity in detecting conductive hearing defects of various magnitudes as determined by pure tone audiometry. To our knowledge these have not been previously reported.

\section{Methods and results}

The Rinne test was done in a standard manner ${ }^{1}$ with $256 \mathrm{~Hz}$ and $512 \mathrm{~Hz}$ tuning forks in 132 patients with otological symptoms, before reading the referral letter, taking the history, examining the patient, or carrying out pure tone audiometry. All patients were tested by both loudness and threshold comparison methods. To compare loudness the forks were presented alternately as air and bone conduction, and the patient was asked to report which was louder. In the comparison threshold method patients reported when they no longer heard the sound by bone conduction and were then asked whether they heard it again when it was presented by air. The responses were classified as Rinne positive if the sound by air conduction was louder than that by bone conduction, Rinne negative if bone conduction was louder than air conduction, and equivocal if the bone conduction and air conduction were equally loud. Subsequently, pure tone audiometric thresholds were assessed by standard methods.

We analysed the results from the better hearing ear (defined as better bone conduction at the frequency of the tuning fork used) to eliminate any potential need to 